\title{
Minicircle DNA vector expressing interferon-lambda-3 inhibits hepatitis B virus replication and expression in hepatocyte-derived cell line
}

Xiaoyan Guo ${ }^{1 \dagger}$, Dianke Chen ${ }^{2 \dagger}$, Qingxian $\mathrm{Cai}^{3}$, Zhanlian Huang ${ }^{1}$, Wenxiong $\mathrm{Xu}^{1}$, Liang Peng ${ }^{{ }^{*}}$ and Ping $\mathrm{Chen}^{4^{*}}$ (D)

\begin{abstract}
Background: Interferon-alpha (IFNa) is a first-line treatment option for chronic hepatitis B virus (HBV) infection, but the severe systemic side-effects limited its clinical application. Interferon-lambda (IFN $\lambda$ ) with comparable antiviral activity and less toxic side-effects is thought to be a good alternative interferon to IFNa. Additionally, the gene vector mediated sustainably expression of therapeutic product in the target cells/tissue may overcome the shortcomings resulted from the short half-life of IFNs.
\end{abstract}

Results: We constructed a liver-specific IFN $\lambda$ 3-expressing minicircle (MC) vector under the control of a hepatocytespecific ApoE promoter (MC.IFN入3) and investigated its anti-HBV activity in a HBV-expressing hepatocyte-derived cell model (HepG2.2.15). As expected, the MC.IFN $\lambda 3$ vector capable of expressing IFN $\lambda 3$ in the recipient hepatocytes has demonstrated robust anti-HBV activity, in terms of suppressing viral antigen expression and viral DNA replication, via activation the interferon-stimulated gene (ISG) expression in HepG2.2.15 cells.

Conclusions: Given the $M C$ vector can be easily delivered into liver, the liver-targeted IFN gene-transfer (MC.IFN $\lambda 3$ ), instead of systemic administrating IFN repeatedly, provides a promising concept for the treatment of chronic HBV infection.

Keywords: Minicircle DNA, Type III interferon, Interferon-stimulated gene, Hepatitis B virus

\section{Background}

Hepatitis B virus (HBV), the causative agent of hepatitis $B$, remains a major threat to public health. It's estimated that more than 240 million people are chronically infected with HBV and over 780,000 people die annually from hepatitis B-related complications $[1,2]$. To date, there are no cures for chronic hepatitis $\mathrm{B}(\mathrm{CHB})$, as the current treatments including the nucleos $(\mathrm{t})$ ide analogues (NAs) and interferon-alpha (IFNo) therapy do not effectively clear HBV from the infected individuals [3]. The NAs targeting the HBV polymerase (or termed

\footnotetext{
* Correspondence: pliang@mail.sysu.edu.cn; pingchen09@gmail.com ${ }^{+}$Xiaoyan Guo and Dianke Chen contributed equally to this work. 'Department of Infectious Diseases, The Third Affiliated Hospital of Sun Yat-Sen University, Guangzhou, China

${ }^{4}$ Shenzhen Institutes of Advanced Technology, Chinese Academy of Sciences, Shenzhen, China

Full list of author information is available at the end of the article
}

reverse transcriptase) can substantially inhibit HBV replication, but it fails to eliminate the pre-existing HBV persistence template-the covalently closed circular DNA (cccDNA) [4]. Apart from the ISG-associated inhibitory activity against HBV replication [5], it's report that the IFN $\alpha$ at high concentration can degrade cccDNA in a noncytopathic manner $[6,7]$. Thus, the IFN $\alpha$ therapy can occasionally result in functional cure of $\mathrm{CHB}$ in some patients, but it suffers severe systemic side-effects as well as poor response rate [4]. Collectively, it's necessary to develop novel anti-HBV agents that can eliminate virus with minimal side-effects.

Since 2003, a new type of interferon that structurally resembles to cytokines IL-10 family members (namely type-III interferon or IFN- $\lambda$ ) has been identified and characterized, including IFN $\lambda 1$ (or IL-29), IFN $\lambda 2$ (or IL28A) and IFN $\lambda 3$ (or IL-28B) [8, 9]. Among the three 
human IFN $\lambda$ isoforms, IFN $\lambda 3$ was shown to have highest antiviral activity in hepatocyte cell model [10]. IFN $\lambda$ and IFN $\alpha$ have distinct extracellular receptors but share similar intracellular Janus kinase/signal transducer and activation of transcription (JAK/STAT) signaling transduction pathway, in response to viral infection [11-13]. Unlike the ubiquitously expressed IFN $\alpha$ receptor; the IFN $\lambda$ receptor primarily distributed on epithelial cells including hepatocytes while expressed little on hematopoietic cells, fibroblasts, microvascular endothelial cells, adipocytes and CNS cells [14]. With restricted target cell types, the application of IFN $\lambda$ as antiviral agent is expected to has less side-effects than IFNa therapy, for example it is less likely to cause leukopenias that is common in IFN $\alpha$ therapy $[12,15,16]$. Recent clinical trials have demonstrated that the IFN $\lambda$ therapy is effective and well-tolerable in human patients with chronic HBV/HDV or HCV infection [17-19]. A phase II clinical trial on patients with $\mathrm{CHB}$ illustrated that the pegylated IFN $\lambda$ led to virological outcomes equivalent to pegylated IFN $\alpha$ while with a better tolerability [20,21]. The phase II Lambda Interferon Monotherapy (LIMT) study sponsored by Eiger BioPharmaceuticals (NCT02765802) has evaluated the safety and efficacy of pegylated IFN $\lambda$ administration for 48 weeks in chronic HDV patients. According to the interim results report, a significant (2-log) HDV-RNA decline was observed in majority of patients, while the adverse side-effects typically seen with INF $\alpha$ were fewer $[19,22]$. These studies suggest that IFN $\lambda$ may be a good alternative treatment against HBV infection.

Owing to the limited in vivo half-life, the IFNs (even for the PEGylated long-acting format) needs to be administrated repeatedly during the long course of treatment (several months), and consequently inconvenience their clinical application. The gene therapy that expressing IFNs in vivo by using a gene vector provides an alternative solution to bypass this limitation. As HBV is a liver tropic virus that specifically infect the hepatocytes, the chronic or persistent HBV infection can be viewed as an acquired genetic liver disease and it's possible that $\mathrm{CHB}$ can be treated by a liver-targeted gene therapy [23]. In this study, we constructed a hepatocyte-specific minicircle DNA (MC) vector encoding IFN $\lambda 3$ gene (MC.IFN入3) and verified its anti-HBV activity in vitro. Where the MC [24] is an bacterial backbone DNA-free non-viral vector which permits stable and highly transgene expression in vitro and in vivo [25-28].

\section{Results}

MC.IFN $\lambda 3$ permits hepatocyte-specific expression of IFN $\lambda 3$ The MC.IFN $\alpha$ (1656 bp in length; Fig. 1a left) or MC.IFN $\lambda 3$ (1677 bp in length; Fig. 1a right) construct under the control of a ApoE promoter was designed to specifically express the corresponding interferon (IFN $\alpha$ or IFN $\lambda 3$ ) only in hepatocytes. To verify this assumption, we determined the expression of IFN $\alpha$ or IFN $\lambda 3$ in a variety of cell lines after 3 days of transfection with MC.IFNs by Western blot, including in HepG2.2.15 (hepatocyte), HEK293 (embryonic kidney cell) and Hela (Cervical squamous cell) cell lines.

Little or no IFN $\alpha /$ IFN $\lambda 3$ signal was detected in MC transfected HEK293 or Hela cells while clear and strong protein signal was shown in the HepG2.2.15 cells transfected with MC.IFNa (Fig. 1b upper row, Lane 2) or MC.IFN $\lambda 3$ (Fig. 1b middle row, Lane 3), illustrating the MC.IFNs constructs permit hepatocyte-specific expression of interferons. The very weak signals of IFN $\alpha$ presented in the untreated HepG2.2.15 cells (control) suggests that it may have baseline (low level) of endogenous IFNa in the HepG2.2.15 cells (Fig. 1b upper row); in contrast, no baseline expression of endogenous IFN $\lambda 3$ was detected in HepG2.2.15 cells (Fig. 1b middle row).

\section{MC.IFN $\lambda 3$ inhibits viral antigens expression and viral DNA replication in HepG2.2.15 cells}

To investigate the anti-HBV activity of the MC.IFNs, the viral DNA and secretory viral antigens (HBsAg and $\mathrm{HBeAg}$ ) in cell culture supernatant from MC.IFNs transfected HepG2.2.15 cells were detected at 3- and 6 days after transfection. Where the transfection efficiency of HepG2.2.15 cells with MC.IFNs was roughly estimated to be about $70 \%$, by using the MC vector, with comparable size ( $1.8 \mathrm{~kb}$ vs $1.7 \mathrm{~kb})$, encoding an enhanced green fluorescent protein (MC.eGFP) as an indicator.

Like MC.IFN $\alpha$, MC.IFN 33 can inhibit both viral antigens (HBsAg and $\mathrm{HBeAg}$ ) expression and viral DNA release (Fig. 2; Table 1). From a statistical perspective, MC.IFN $\lambda 3$ and MC.IFN $\alpha$ shows comparable anti-HBV activity at day 3 post-transfection $(P>0.05)$, although the inhibition rate of MC.IFN $\lambda 3$ seems slight lower than that of MC.IFN $\alpha$ (MC.IFN $\lambda 3$ vs MC.IFN $\alpha$ were $24.8 \%$ vs $35.1 \%$ for $\mathrm{HBsAg}, 26.5 \%$ vs $34.5 \%$ for $\mathrm{HBeAg}$, $43.3 \%$ vs $53.6 \%$ for viral DNA); while after 6 days of transfection, MC.IFN $\lambda 3$ shows statistically stronger $(P<0.05)$ antiviral activities in comparison with its counterpart MC.IFN $\alpha$, as the separate inhibition rates of viral antigens and viral DNA (MC.IFN $\lambda 3$ vs MC.IFNa were $36.7 \%$ vs $16.2 \%$ for $\mathrm{HBsAg}$, $39.9 \%$ vs $20.9 \%$ for $\mathrm{HBeAg}, 50.3 \%$ vs $33.7 \%$ for viral DNA) (Table 1).

\section{MC.IFN $\lambda 3$ induces JAK1 and STAT1/STAT2 phosphorylation in HepG2.2.15 cells}

The un-phosphorylated and phosphorylated (p-STATs) form of STAT1/STAT2 both in cell nucleus and in cytoplasm of MC transfected HepG2.2.15 cells were determined by Western blot at 6 days post-transfection. The 


\section{A}

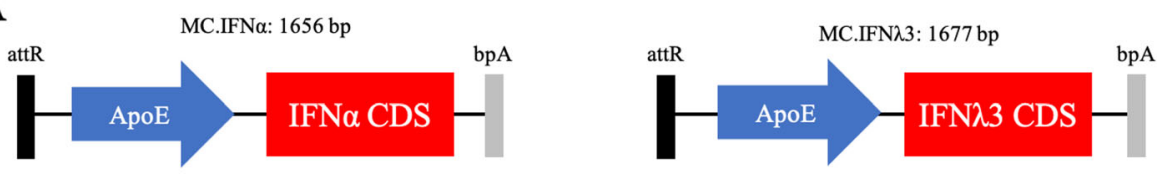

B

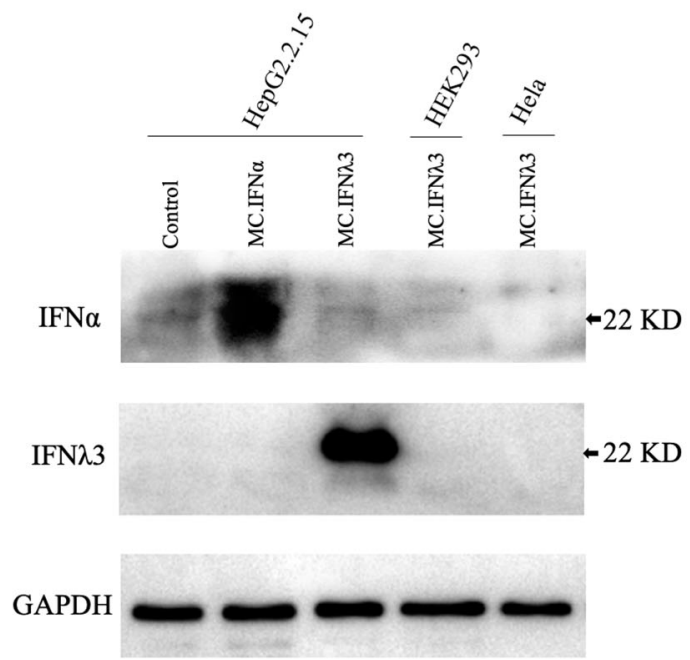

Fig. 1 MC.IFN入3 permits hepatocyte-specific expression of IFN 3 . HepG2.2.15, HEK293 and Hela cells were transfected with MC vectors. a Schematic illustration of the MC.IFNs. MC.IFNa is 1656 -bp in length, MC.IFN 3 is 1677-bp in length. attR represents a 36-bp attR recombinant site. ApoE indicates ApoE promoter. CDS represents coding sequence. bpA represents bovine growth hormone polyadenylation signal. $\mathbf{b}$ The expression of IFNa and IFN 3 in cell lysate was determined by Western Blot at 3 days post-transfection. Lane 1-5 represents the untreated control (HepG2.2.15 cells without MC transfection), MC.IFNa transfected HepG2.2.15 cells, and MC.IFN $\lambda 3$ transfected HepG2.2.15 cells, MC.IFN 33 transfected HEK293 cells, MC.IFN $\lambda 3$ transfected Hela cells, respectively

expression pattern differs significantly between cell nucleus (Fig. 3a left) and cytoplasm (Fig. 3a right). Except p-STAT1, STAT1, STAT2 and p-STAT2 are clearly expressed in the cytoplasm of the MC.IFNs-untreated cells (control) (Fig. 3a right). In contrast, the weak signals of STAT1, STAT2 and p-STAT2 in cell nucleus from the control samples also have been detected, indicating that there is baseline level of nuclear STAT1, STAT2 and p-STAT2 in the untreated cells (Fig. 3a left). For quantitative comparison of STATs/p-STATs among different groups, we estimated the relative levels of STATs/p-STATs by calculating the intensity of immunoblotting bands using the software Image J. We found that both MC.IFNs treatment dramatically increased the level of intra-nuclear STAT1 for about 13 $(\mathrm{MC} . I F N \alpha)$ or 14 (MC.IFN $\lambda 3)$ times with a comparable level $(\mathrm{MC} . \mathrm{IFN} \lambda 3 / \mathrm{MC} . \mathrm{IFN \alpha}=1.06)$ (Fig. 3a). As comparable signals were detected among control and two MC.IFNs treated samples (control: MC.IFNo: MC.IFN $\lambda 3=0.9: 1: 1.2$ ), we speculated that either MC.IFN $\alpha$ or MC.IFN $\lambda 3$ had little effect on the level of cytoplasmic STAT1 (Fig. 3a). The MC.IFNs treatment was also found to induce the comparably while significantly increase of the STAT2 levels both in cytoplasm
(MC.IFN $\alpha$ vs control: 2.9 times; MC.IFN $\lambda 3$ vs control: 2.2 times; $\mathrm{MC}$.IFN $\alpha / \mathrm{MC}$.IFN $\lambda 3=1.3$ ) and nucleus (MC.IFN- $\alpha$ vs control: 2.7 times; MC.IFN $\lambda 3$ vs control: 3.1 times; $\mathrm{MC}$.IFN $/ \mathrm{MC}$.IFN $\lambda 3=1.1$ ) for about 2 to 3 times (Fig. 3a). Given the cytoplasmic and nuclear pSTAT1 signals were presented in MC.IFN $\alpha$ or MC.IFN $\lambda 3$ treated cells but was absent in the control cells (Fig. 3a), it suggested that each MC.IFN can induce the phosphorylation of STAT1. Furthermore, the MC.IFN $\lambda 3$ showed a stronger ability to activate phosphorylation of STAT1 (MC.IFN $\lambda 3 / \mathrm{MC}$.IFN $\alpha=2.07$ in cytoplasm; MC.IFN $\lambda 3 / \mathrm{MC}$.IFN $\alpha=1.9$ in nucleus) and both MC.IFNs were found to be able to comparably $(\mathrm{MC} . I F N \lambda 3 / \mathrm{MC} . I F N \alpha=1.02)$ elevate the nuclear $\mathrm{p}$ STAT2 amount from baseline low level to a relative higher level for about 16 times (control: MC.IFNa: MC.IFN $\lambda 3=1: 15.9: 16.3$ ) (Fig. 3a). These findings suggest that both MC.IFNs may up-regulate STAT2 expression, trigger the STAT1/STAT2 transferring from cytoplasm to nucleus and induce the phosphorylation of STAT1/ STAT2.

To further investigate the activation of relevant upstream kinase of STAT1/STAT2 in JAK/STAT pathway, the JAK1 and phosphorylated JAK1 (p-JAK1) in MC 

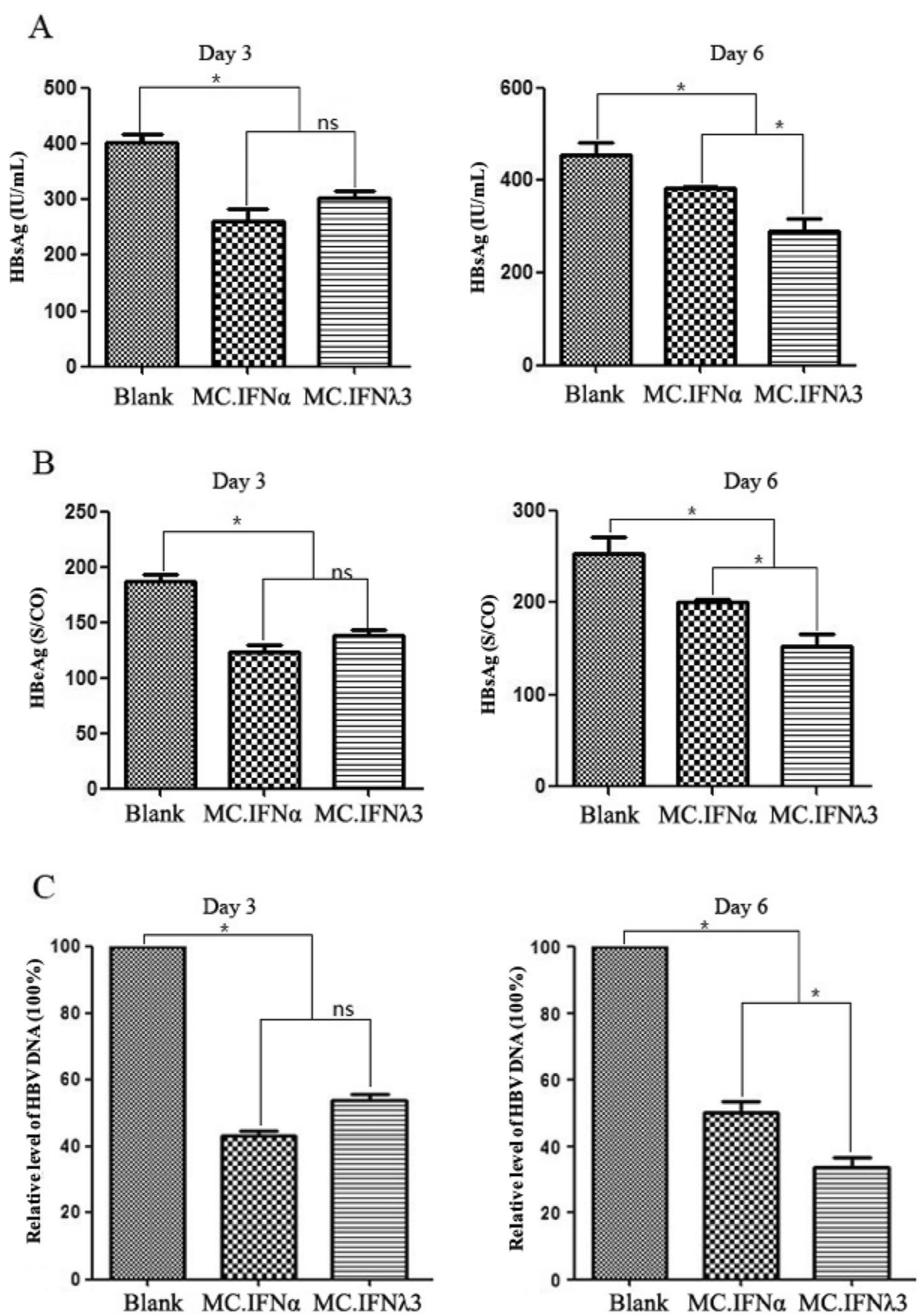

Fig. 2 MC.IFN $\lambda 3$ inhibits viral antigens expression and viral DNA replication in HepG2.2.15 cells. HepG2.2.15 cells were transfected with MC.IFN $\lambda 3$ and MC.IFNa. While the untreated HepG2.2.15 cells served as a blank control (Blank). The levels of viral antigens, namely HBsAg (a) and HBeAg (b), and viral DNA in cell culture supernatant were determined by chemiluminiscence and GPCR, respectively, at the indicated time-points (3 or 6 days post-transfection). All data are shown as mean \pm SD from three independent experiments. ${ }^{*}$ indicates statistically significant $(P$-value $<0.05)$, ns indicates not significant $(P$-value $>0.05)$

transfected HepG2.2.15 cells were determined by Western blot at the same time point, namely 6 days posttransfection. Weak expression of JAK1 was shown in MC-untreated (control) cells (Fig. 3b upper row, Lane 1 ), while the increased expression of JAK1 in were observed in both MC.IFN $\alpha$ and MC.IFN $\lambda 3$ transfected cells (Fig. 3b upper row, Lane 2 and 3). On the other hand, the phosphorylated JAK1 (p-JAK1) was presented in both MC.IFNs treated cells (Fig. 3b middle row, Lane 2 and 3) but absent in the control cells (Fig. 3b middle 
Table 1 Viral antigens and viral DNA in HepG2.2.15 cell culture supernatant after transfection

\begin{tabular}{|c|c|c|c|c|c|c|c|}
\hline & \multirow{2}{*}{$\begin{array}{l}\text { Time } \\
\text { Points }\end{array}$} & \multicolumn{3}{|l|}{ Group } & \multicolumn{3}{|c|}{$P$-value } \\
\hline & & Control (1) & MC.IFNa (2) & $\overline{M C . I F N \lambda 3(3)}$ & 2 vs. 1 & 3 vs. 1 & 3 vs. 2 \\
\hline \multirow[t]{2}{*}{$\mathrm{HBsAg}(\mathrm{IU} / \mathrm{mL})$} & day 3 & $403.3 \pm 26.2$ & $261.4 \pm 36.1$ & $303.3 \pm 20.6$ & $* *$ & $* *$ & ns \\
\hline & day 6 & $456.4 \pm 45.1$ & $382.5 \pm 5.8$ & $288.9 \pm 50.9$ & * & $* *$ & * \\
\hline \multirow[t]{2}{*}{ HBeAg (S/CO) } & day 3 & $187.6 \pm 10.7$ & $122.8 \pm 12.1$ & $137.9 \pm 9.4$ & $* *$ & $* *$ & ns \\
\hline & day 6 & $253.4 \pm 30.4$ & $200.2 \pm 5.3$ & $152.2 \pm 20.7$ & $*$ & $* *$ & * \\
\hline \multirow[t]{2}{*}{ HBV DNA (100\%) } & day 3 & $1.00 \pm 0.017$ & $0.436 \pm 0.034$ & $0.536 \pm 0.020$ & $* *$ & $* *$ & ns \\
\hline & day 6 & $1.01 \pm 0.005$ & $0.50 \pm 0.03$ & $0.34 \pm 0.03$ & $* *$ & $* *$ & * \\
\hline
\end{tabular}

** indicates $P<0.01$; * indicates $P<0.05$; ns represents not significant $(P>0.05)$. Group 1, 2 and 3 represent Control, MC.IFNa and MC.IFN $\lambda 3$ group, respectively

row, Lane 1). These results suggest both MC.IFNs can up-regulate JAK1 expression and active the phosphorylation of JAK1.

Collectively, it's clear that both MC.IFN and MC.IFN $\lambda 3$ may activate JAK/STAT pathway in HepG2.2.15 cells.

\section{MC.IFN $\lambda 3$ up-regulates ISGs expression in HepG2.2.15} cells

To further compare the ISGs expression profile alternation in HepG2.2.15 cells after MC.IFN treatment
(MC.IFN $\lambda 3$ vs MC.IFN $\alpha$ ), the relative mRNA transcriptional levels of ten ISGs (IRF7, IRF9, Apobec3G, Mx1, BST2, PKR, OAS, IFT44, ISG15 and ISG56) of MC transfected HepG2.2.15 cells were quantified at 3 or 6 days post-transfection by qPCR.

Although with common feature that either $\mathrm{MC}$ upregulated all the ten ISGs' mRNA expression in each time-points (at 3 or 6 days post-transfection), the ISG expression profile under the induction of these two MC.IFNs showed significant different pattern across the time-course (Fig. 4). Firstly, we compared the change of

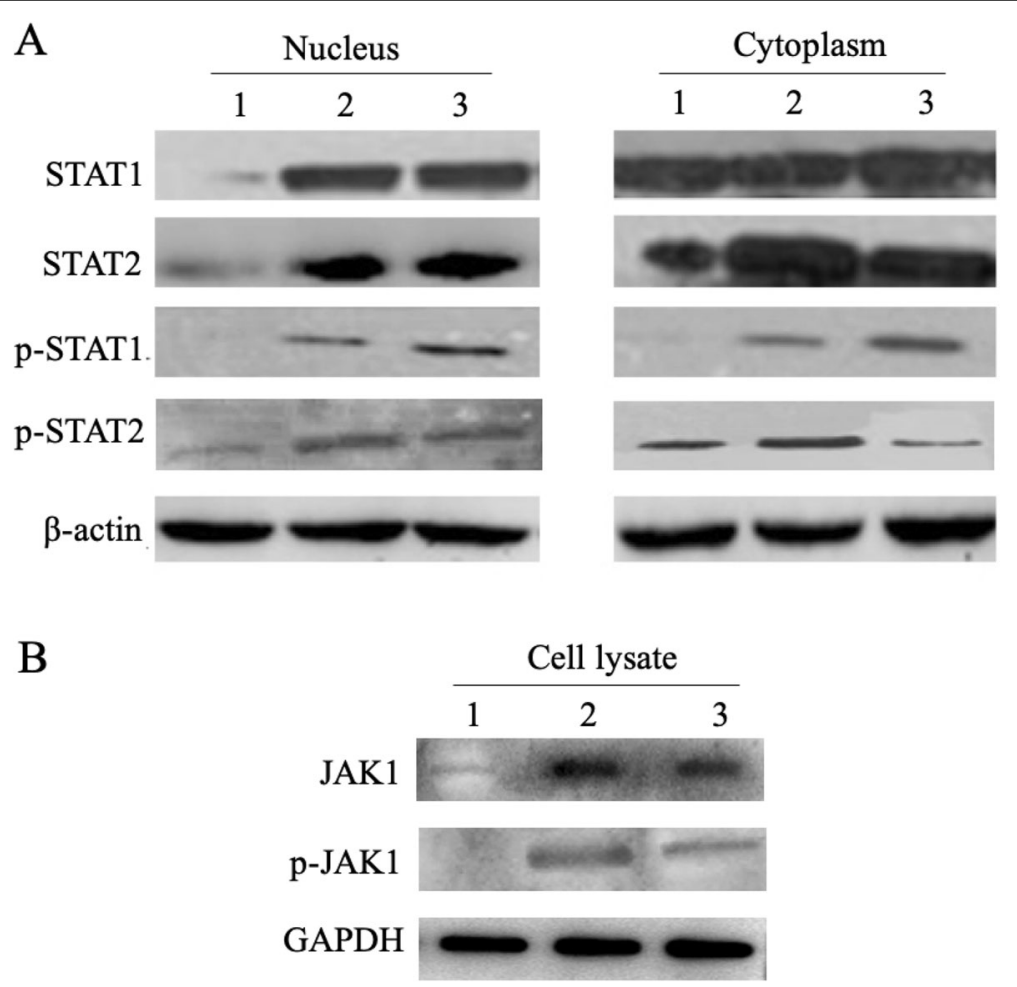

Fig. 3 MC.IFNA3 induce JAK1 and STAT1/STAT2 phosphorylation in HepG2.2.15 cells. HepG2.2.15 cells were transfected with MC vectors. The levels of a STAT1/STAT2 proteins and their phosphorylated form (p-STAT1/p-STAT2), b JAK1 and phosphorylated JAK1 (p-JAK1) in transfected HepG2.2.15 cells were determined by Western Blot at 6 days post-transfection. Lane 1, 2 and 3 represents untreated Control, MC.IFNa, and MC.IFN入3 group, respectively 


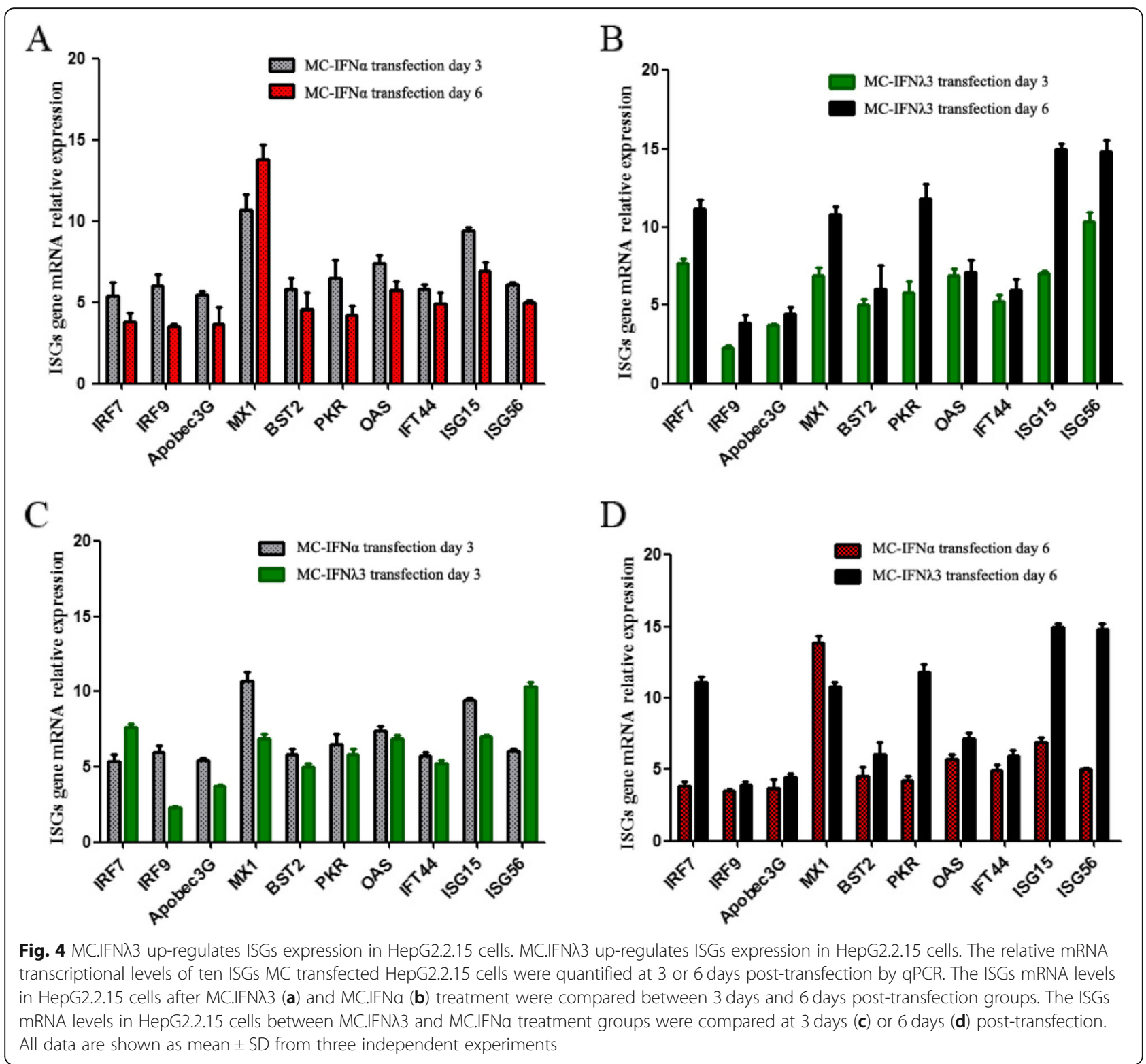

mRNA relative expression level between two different time points (day 3 vs day 6 post-transfection). Compared with day 3 , The expression of all but one (Mx1) ISGs, under MC.IFN- $\alpha$ induction, at day 6 was decreased (Fig. 4a); while all the ISGs expression induced by MC.IFN $\lambda 3$ is ever-increased over time (Fig. 4b). Furthermore, we compared the expression difference between two $\mathrm{MC}$

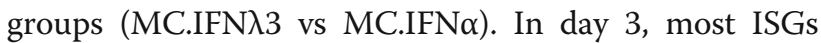
(except IRF7 and ISG56) in MC.IFN $\alpha$ groups expressed much more mRNAs than MC.IFN $\lambda 3$ group (Fig. 4c); while it was completely reversed that the MC.IFN $\lambda 3$ group expressed more mRNAs of all ISGs but Mx1 than MC.IFN $\alpha$ group at day 6 post-transfection (Fig. 4d). These data demonstrated that, in comparison with IFN $\alpha$,
MC.IFN $\lambda 3$ may induce a relative weaker ISGs-response in a short time, but the response is more robust in a prolonged period.

\section{Discussion}

IFN $\lambda$ has exerted significant antiviral activities against HBV or HCV [29-32] and is thought to be a potential alternative agent to IFN $\alpha$ against $\mathrm{HBV} / \mathrm{HCV}$ infection [12]. Compared with IFN $\alpha$ that corresponds to ubiquitously expressed IFN $\alpha$ receptor, IFN $\lambda$ may induce less side-effects as the IFN $\lambda$ receptors are restrictedly expressed in epithelial cells including hepatocyte [14]. In fact, a recent clinical trial has showed that, compared to peg- to those of peg-IFN $\alpha$, the PEGylated IFN $\lambda$ exerts 
comparable serologic/virologic responses at end-oftreatment but less side-effects during on-treatment in CHB patients [20].

Given the long course of IFN-based anti-HBV therapies (months to 1 year), the IFNs with limited half-life are required to be repeatedly administrated weekly (pegylated) or more frequently [33, 34]; therefore, the clinical application of current IFNs is inconvenient and costly. Rather than extending the half-life, the gene therapy that persistently expressing IFN in vivo using an appropriate gene vector provides an alternative way to overcome these drawbacks. As HBV specifically infect the hepatocytes of the liver, chronic or persistent HBV infection can be considered as an acquired liver genetic disease. Thus, local gene expression of therapeutics product in the liver (or termed liver-targeted gene therapy) may be an attractive strategy against chronic HBV infection. By constructing a MC.IFN $\lambda 3$ vector under the control of a liver-specific ApoE promoter that permits sustained IFN $\lambda 3$ production in recipient hepatocyte cells, here we offered a liver-targeted long-acting alternative anti-HBV strategy. For liver-targeting, the non-viral $\mathrm{MC}$ vector, on one hand, can be delivered into liver easily via hydrodynamic tail vein injection [26, 35], the liver-specific ApoE promoter, on the other hand, will drive a specific expression of IFN $\lambda 3$ in hepatocytes (Fig. 1).

In consistence with previous reports [11, 12], we confirmed that MC.IFN $\lambda 3$, like the MC.IFN $\alpha$ counterpart, can induce efficient anti-HBV activity, in terms of suppressing HBV replication and expression, by activating the interferon-stimulated gene (ISG) expression (Fig. 4) through JAK/STAT pathway (Fig. 3). Furthermore, we found that, in comparison with MC.IFN $\alpha$, MC.IFN $\lambda 3$ induced a slightly weaker antiviral response in the earlier stage while a significant stronger antiviral response in the later stage, suggesting a robust inhibitory activity across the long course of IFN $\lambda 3$ treatment (Fig. 2, Table 1).

We have noticed that the efficacy as well as the tolerance profiles of MC.IFN $\lambda 3$ needs to be further evaluate in vivo with animal models. Nevertheless, our data are valuable for developing IFN $\lambda$ 3-based gene therapy against $\mathrm{HBV}$ infection.

\section{Conclusions}

For chronic HBV infection treatment, the MC vector expressing IFN $\lambda 3$ (MC.IFN $\lambda 3$ ) provides a potential alternative strategy to the current IFN therapy.

\section{Methods}

\section{Vector construction and minicircle DNA production}

To construction the minicircle (MC) parental plasmid (PP) of IFN $\lambda 3$ or IFN $\alpha$, the coding sequences (CDS) of IFN $\lambda 3$ and IFN $\alpha$ were separately sub-cloned into a modified minicircle-cloning vector pMC.BESXP [24] with additional hepatocyte-specific ApoE promoter, multiple cloning site (MCS) and bovine growth factor polyadenylation signal.

Using the standard $\mathrm{MC}$ preparation protocol described previously [24], the MCs encoding IFN 33 (MC.IFN $\lambda 3$ )

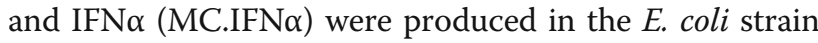
ZYCY10P3S2T22 [24] transformed with corresponding parental plasmid.

\section{Cell culture and transfection}

HEK293 cell, Hela cell and the HBV-positive HepG2.2.15 cell, purchased from Typical Culture Preservation Commission Cell Bank, Chinese Academy of Sciences (Shanghai, China), was maintained in Dulbecco's modified Eagle's medium (DMEM) supplemented with $10 \%$ fetal bovine serum (FBS) at $37^{\circ} \mathrm{C}$ in a moist atmosphere containing $5 \% \mathrm{CO}_{2}$. After $24 \mathrm{~h}$ of seeding at a density of $5 \times 10^{5}$ cells per well of 6 -well plates, the cells were transfected with $2 \mu \mathrm{g}$ MC vector per well mixed with Lipofectamine 2000 (Invitrogen, US) according to the manufacturer's instructions.

\section{Determination of viral DNA and antigens in cell culture supernatant}

The level of secreted HBsAg and HBeAg in the cell culture supernatant was determined periodically by chemiluminiscence using the Abbott ARCHITECT platform (Abbott Laboratories, USA), according to the manufacturer's instructions.

The HBV DNA in the cell culture supernatant was quantified by a TaqMax probe-based quantitative PCR method as performed according to the manufacturer's instructions, using the COBAS ${ }^{\bullet} \mathrm{TaqMan}^{\bullet} \mathrm{HBV}$ Test Kit (Roche Diagnostics, US).

\section{Quantitative real-time PCR}

The mRNA transcription level of ISGs was determined by quantitative real-time PCR. Total mRNA was isolated from the MC transfected cells at the indicated time points using TRIZOL (invitrogen, US). The RNA quantity and quality was measured using a NanoDrop2000 spectrophotometer (Thermo Scientific, US). Subsequently, cDNA was reverse transcribed and subjected to quantitative PCR (qPCR) with the $\mathrm{SYBR}^{\circ}$ Premix Ex TaqTM II kit (TaKaRa, Japan). The ISG-specific qPCR primers are listed in Table 2.

The thermal cycling conditions were as follows: 30 s at $95^{\circ} \mathrm{C}$, followed by 40 cycles of $95^{\circ} \mathrm{C}$ for $10 \mathrm{~s}, 55^{\circ} \mathrm{C}$ for 10 $\mathrm{s}$, and $72^{\circ} \mathrm{C}$ for $15 \mathrm{~s}$. The relative abundance of a given transcript was estimated using the $2^{-\Delta \Delta} \mathrm{Ct}$ method, following normalization to $ß$-actin. 
Table 2 The qPCR primer pairs for detecting ISG genes

\begin{tabular}{lll}
\hline Genes & Primer pairs & \\
\cline { 2 - 3 } & Forward & Reverse \\
\hline IRF9 & gccctacaaggtgtatcagttg & tgctgtcgctttgatggtact \\
IRF7 & gctggacgtgaccatcatgta & gggccgtataggaacgtgc \\
PKR & gccgctaaacttgcatatcttca & tcacacgtagtagcaaaagaacc \\
ISG56 & ttgatgacgatgaaatgcctga & caggtcaccagactcctcac \\
IFNAR2 & tcatggtgtatatcagcctcgt & agttggtacaatggagtggtttt \\
Mx1 & gtttccgaagtggacatcgca & ctgcacaggttgttctcagc \\
OAS & ctgatgcaggaactgtatagcac & cacagcgtctagcacctctt \\
ISG15 & cgcagatcacccagaagatcg & ttcgtcgcatttgtccacca \\
IFI44L & agccgtcagggatgtactataac & agggaatcatttggctctgtaga \\
IFITM1 & ccaaggtccaccgtgattaac & atgaaccacattgtgcaaacct \\
Apobec3G & gcatcgtgaccaggagtatga & gtcagggtaaccttcgggt \\
B-actin & gccgggacctgactgacacctcat & tttgcggtggacgatggagg \\
\hline
\end{tabular}

\section{Western blot}

The protein samples were separated by SDS-PAGE and then transferred to a polyvinylidene difluoride (PVDF) membrane (Millipore, US). After blocked the nonspecific binding sites with $5 \%$ skim milk in TBST (Sigma, US), the membrane was subjected to immunoblotting using a primary antibody listed as below: the rabbit polyclonal antibody specific to IFNa (ProteinTech, US; \#18013-1-AP) and IFN入3 (ProteinTech, US; \#24199-1$\mathrm{AP})$; the rabbit monoclonal antibodies specific to JAK1 (Cell Signaling Technology, US; \#3344) and phosphorylated JAK1 (p-JAK1) (Cell Signaling Technology, US; \#3331); the rabbit polyclonal or monoclonal antibodies specific to STAT1 (Abcam, UK; \#ab2415), STAT2 (Abcam, UK; \#ab53149), phosphorylated STAT1 (pSTAT1) (Cell Signaling Technology, US; \#9171) and phosphorylated STAT2 (p-STAT2) (Millipore, US; \#07224). Finally, horseradish peroxidase-conjugated goatanti-rabbit IgG secondary antibody (ProteinTech, US) and chemiluminescence system ECL Kit (Thermo Scientific, US) were used to visualize protein signal. For normalization, the housekeeping protein $\beta$-actin or GAPDH present on the same blots was detected using an anti- $\beta$ actin antibody (ProteinTech, US) or antiGAPDH antibody (Kangcheng BioTech, Shanghai, China).

The relative quantification of detected proteins on Western blotting was performed with the software Image J (https://imagej.nih.gov/ij/download.html) by estimating the intensity (or termed gray scale) of corresponding bands.

\section{Statistical methods}

Mean and SD (or SEM) was calculated for each dataset. The statistical difference between two experimental groups (MC.IFNa vs MC.IFN入3) were compared using Student's t-test; while the statistical comparison among multiple groups ( $\geq 3$ groups) were performed with oneway ANOVA, following a Dunnett's post-hoc tests. $P$ value $<0.05$ (*) was considered statistically significant. All these analyses were performed with Graphpad Prism 8 software (GraphPad Software, Inc., San Diego, CA).

\section{Abbreviations}

cccDNA: covalently closed circular DNA; CDS: Coding sequences; hAAT: human alpha-1 antitrypsin; HBeAg: Hepatitis B e antigen; HBsAg: Hepatitis B surface antigen; HBV: Hepatitis B virus; HCV: Hepatitis C virus; HDV: Hepatitis D virus; IFNa: Interferon-alpha; IFN- $\lambda$ : Interferon-lambda; ISG: Interferon-stimulated gene; JAK/STAT: Janus kinase/signal transducer and activation of transcription; MC: Minicircle; MCS: Multiple cloning site; NAs: Nucleos(t) ide analogues; PP: Parental plasmid; qPCR: quantitative Polymerase Chain Reaction

\section{Acknowledgements \\ The grateful assistance of professor ZY Chen is recognized and appreciated.}

\section{Authors' contributions}

$X Y G, D K C$ and PC conceived the study, participated in its design and coordination, and managed the preparation of the manuscript. LP and XYG performed the statistical analyses and analyzed the results. WXX, ZLH and QXC provided the clinical data. All authors read and approved the final manuscript.

\section{Funding}

This work was supported by the National Natural Science Foundation of China (Grant no. 81700531, 81500448) and the Guangdong Provincial Scientific Research Foundation (Grant no. 2014A030310420). The Funders provided the financial supports for functional experiments and publication costs, but had no role in the design of the study, the collection, analysis and interpretation of data and the writing of manuscript.

\section{Availability of data and materials}

Not applicable.

Ethics approval and consent to participate

This article does not contain any studies with human participants or animals performed by any of the authors.

\section{Consent for publication}

Not applicable.

\section{Competing interests}

The authors declare that they have no competing interests.

\section{Author details}

${ }^{1}$ Department of Infectious Diseases, The Third Affiliated Hospital of Sun Yat-Sen University, Guangzhou, China. ${ }^{2}$ Department of Medical Oncology, The Sixth Affiliated Hospital, Sun Yat-Sen University, Guangzhou, China. ${ }^{3}$ Department of Hepatology, The Third People's Hospital of Shenzhen, Shenzhen, China. ${ }^{4}$ Shenzhen Institutes of Advanced Technology, Chinese Academy of Sciences, Shenzhen, China.

Received: 5 October 2019 Accepted: 6 February 2020

Published online: 18 February 2020

\section{References}

1. Tang LSY, Covert E, Wilson E, Kottilil S. Chronic hepatitis B infection: a review. JAMA. 2018:319(17):1802-13.

2. Revill PA, Locarnini SA. New perspectives on the hepatitis B virus life cycle in the human liver. J Clin Invest. 2016;126(3):833-6.

3. Yuen MF, Chen DS, Dusheiko GM, Janssen HLA, Lau DTY, Locarnini SA, Peters MG, Lai CL. Hepatitis B virus infection. Nat Rev Dis Primers. 2018;4: 18035. 
4. Kang L, Pan J, Wu J, Hu J, Sun Q, Tang J. Anti-HBV drugs: Progress, unmet needs, and new Hope. Viruses. 2015;7(9):4960-77.

5. Tan $G$, Song $H$, Xu F, Cheng G. When hepatitis B virus meets Interferons. Front Microbiol. 2018:9:1611.

6. Lucifora J, Xia Y, Reisinger F, Zhang K, Stadler D, Cheng X, Sprinzl MF, Koppensteiner H, Makowska Z, Volz T, et al. Specific and nonhepatotoxic degradation of nuclear hepatitis B virus cccDNA. Science. 2014;343(6176): 1221-8.

7. Ding S, Robek MD. Cytidine deamination and $\operatorname{cccDNA}$ degradation: a new approach for curing HBV? Hepatology. 2014;60(6):2118-21.

8. Kotenko SV, Gallagher G, Baurin W, Lewis-Antes A, Shen M, Shah NK, Langer JA, Sheikh F, Dickensheets H, Donnelly RP. IFN-lambdas mediate antiviral protection through a distinct class II cytokine receptor complex. Nat Immunol. 2003:4(1):69-77.

9. Sheppard P, Kindsvogel W, Xu W, Henderson K, Schlutsmeyer S, Whitmore TE, Kuestner R, Garrigues U, Birks C, Roraback J, et al. IL-28, IL-29 and their class II cytokine receptor IL-28R. Nat Immunol. 2003:4(1):63-8.

10. Dellgren C, Gad HH, Hamming OJ, Melchjorsen J, Hartmann R. Human interferon-lambda3 is a potent member of the type III interferon family. Genes Immun. 2009;10(2):125-31.

11. Pagliaccetti NE, Chu EN, Bolen CR, Kleinstein SH, Robek MD. Lambda and alpha interferons inhibit hepatitis $B$ virus replication through a common molecular mechanism but with different in vivo activities. Virology. 2010; 401(2):197-206.

12. Pagliaccetti NE, Robek MD. Interferon-lambda in the immune response to hepatitis B virus and hepatitis C virus. J Interf Cytokine Res. 2010;30(8):58590.

13. Zhang L, Jilg N, Shao RX, Lin W, Fusco DN, Zhao H, Goto K, Peng LF, Chen WC, Chung RT. IL28B inhibits hepatitis C virus replication through the JAKSTAT pathway. J Hepatol. 2011;55(2):289-98.

14. Sommereyns C, Paul S, Staeheli P, Michiels T. IFN-lambda (IFN-lambda) is expressed in a tissue-dependent fashion and primarily acts on epithelial cells in vivo. PLoS Pathog. 2008;4(3):e1000017.

15. Ramos EL. Preclinical and clinical development of pegylated interferonlambda 1 in chronic hepatitis C. J Interf Cytokine Res. 2010;30(8):591-5.

16. Dickensheets H, Sheikh F, Park O, Gao B, Donnelly RP. Interferon-lambda (IFN-lambda) induces signal transduction and gene expression in human hepatocytes, but not in lymphocytes or monocytes. J Leukoc Biol. 2013; 93(3):377-85.

17. Muir AJ, Shiffman ML, Zaman A, Yoffe B, de la Torre A, Flamm S, Gordon SC, Marotta P, Vierling JM, Lopez-Talavera JC, et al. Phase 1b study of pegylated interferon lambda 1 with or without ribavirin in patients with chronic genotype 1 hepatitis C virus infection. Hepatology. 2010;52(3):822-32.

18. Phillips S, Mistry S, Riva A, Cooksley H, Hadzhiolova-Lebeau T, Plavova S, Katzarov K, Simonova M, Zeuzem S, Woffendin C, et al. Peg-interferon lambda treatment induces robust innate and adaptive immunity in chronic hepatitis B patients. Front Immunol. 2017:8:621.

19. Hamid SS, Etzion O, Lurie Y, Bader N, Yardeni D, Channa SM. A phase 2 randomized clinical trial to evaluate the safety and efficacy of pegylated interferon lambda monotherapy in patients with chronic hepatitis delta virus infection. In: Interim results from the LIMT HDV Study. Washington DC: AASLD; 2017. Hepatology.

20. Chan HLY, Ahn SH, Chang TT, Peng CY, Wong D, Coffin CS, Lim SG, Chen $P J$, Janssen $H L A$, Marcellin P, et al. Peginterferon lambda for the treatment of HBeAg-positive chronic hepatitis B: a randomized phase $2 b$ study (LIRAB). J Hepatol. 2016;64(5):1011-9.

21. Mentha N, Clement S, Negro F, Alfaiate D. A review on hepatitis D: from virology to new therapies. J Adv Res. 2019;17:3-15.

22. Loglio A, Segato S, Lampertico P. Hepatitis D - how is the fight against this foe going? Expert Rev Clin Pharmacol. 2019;12(3):169-71.

23. Protzer U, Nassal M, Chiang PW, Kirschfink M, Schaller H. Interferon gene transfer by a hepatitis B virus vector efficiently suppresses $\backslash$ wild-type virus infection. Proc Natl Acad Sci U S A. 1999;96(19):10818-23.

24. Kay MA, He CY, Chen ZY. A robust system for production of minicircle DNA vectors. Nat Biotechnol. 2010;28(12):1287-9.

25. Gaspar V, de Melo-Diogo D, Costa E, Moreira A, Queiroz J, Pichon C, Correia I, Sousa F. Minicircle DNA vectors for gene therapy: advances and applications. Expert Opin Biol Ther. 2015;15(3):353-79.

26. Gracey Maniar LE, Maniar JM, Chen ZY, Lu J, Fire AZ, Kay MA. Minicircle DNA vectors achieve sustained expression reflected by active chromatin and transcriptional level. Mol Ther. 2013;21(1):131-8.
27. Chen ZY, He CY, Ehrhardt A, Kay MA. Minicircle DNA vectors devoid of bacterial DNA result in persistent and high-level transgene expression in vivo. Mol Ther. 2003;8(3):495-500.

28. Chen ZY, He CY, Kay MA. Improved production and purification of minicircle DNA vector free of plasmid bacterial sequences and capable of persistent transgene expression in vivo. Hum Gene Ther. 2005;16(1):126-31.

29. Donnelly RP, Dickensheets H, O'Brien TR. Interferon-lambda and therapy for chronic hepatitis C virus infection. Trends Immunol. 2011;32(9):443-50.

30. Hermant P, Demarez C, Mahlakoiv T, Staeheli P, Meuleman P, Michiels T. Human but not mouse hepatocytes respond to interferon-lambda in vivo. PLoS One. 2014;9(1):e87906.

31. Robek MD, Boyd BS, Chisari FV. Lambda interferon inhibits hepatitis B and C virus replication. J Virol. 2005;79(6):3851-4.

32. Xu F, Song H, Xiao Q, Li N, Zhang H, Cheng G, Tan G. Type III interferoninduced CBFbeta inhibits HBV replication by hijacking HBx. Cell Mol Immunol. 2019;16(4):357-66.

33. Terrault NA, Bzowej NH, Chang KM, Hwang JP, Jonas MM, Murad MH. American Association for the Study of Liver D: AASLD guidelines for treatment of chronic hepatitis B. Hepatology. 2016;63(1):261-83.

34. Sarin SK, Kumar M, Lau GK, Abbas Z, Chan HL, Chen CJ, Chen DS, Chen HL, Chen PJ, Chien RN, et al. Asian-Pacific clinical practice guidelines on the management of hepatitis B: a 2015 update. Hepatol Int. 2016:10(1):1-98

35. Zhang G, Budker $V$, Wolff JA. High levels of foreign gene expression in hepatocytes after tail vein injections of naked plasmid DNA. Hum Gene Ther. 1999;10(10):1735-7.

\section{Publisher's Note}

Springer Nature remains neutral with regard to jurisdictional claims in published maps and institutional affiliations.
Ready to submit your research? Choose BMC and benefit from:

- fast, convenient online submission

- thorough peer review by experienced researchers in your field

- rapid publication on acceptance

- support for research data, including large and complex data types

- gold Open Access which fosters wider collaboration and increased citations

- maximum visibility for your research: over $100 \mathrm{M}$ website views per year

At BMC, research is always in progress.

Learn more biomedcentral.com/submissions 